\title{
Hydraulic conductivity and diffusivity of an Oxisol cultivated with sugarcane
}

\section{fertigated with nitrogen and potassium}

\author{
Condutividade hidráulica e difusividade de um Latossolo Vermelho cultivado com cana-de-açúcar \\ fertirrigada com nitrogênio e potássio \\ Conductividad hidráulica y difusividad de un Oxisol cultivado con caña de azúcar fertilizada con \\ nitrógeno y potasio
}

Received: 04/23/2021 | Reviewed: 05/03/2021 | Accept: 05/12/2021 | Published: 05/29/2021

\author{
Fernando Nobre Cunha \\ ORCID: https://orcid.org/0000-0001-8489-7625 \\ Instituto Federal de Educação, Ciência e Tecnologia Goiano, Brazil \\ E-mail: fernandonobrecunha@hotmil.com \\ Marconi Batista Teixeira \\ ORCID: https://orcid.org/0000-0002-0152-256X \\ Instituto Federal de Educação, Ciência e Tecnologia Goiano, Brazil \\ E-mail: marconibt@gmail.com \\ Nelmício Furtado da Silva \\ ORCID: https://orcid.org/0000-0001-7055-8075 \\ Instituto Federal de Educação, Ciência e Tecnologia Goiano, Brazil \\ E-mail: nelmiciofurtado@gmail.com \\ Fernando Rodrigues Cabral Filho \\ ORCID: https://orcid.org/0000-0002-5090-5946 \\ Instituto Federal de Educação, Ciência e Tecnologia Goiano, Brazil \\ E-mail: fernandorcfilho10@gmail.com \\ Daniely Karen Matias Alves \\ ORCID: https://orcid.org/0000-0001-7427-7545 \\ Instituto Federal de Educação, Ciência e Tecnologia Goiano, Brazil \\ E-mail: daniely_karen@hotmail.com
}

\begin{abstract}
This study had the objective to evaluate the effect of irrigation and fertigation (NK) in the hydraulic conductivity and diffusivity of an Oxisol cultivated with sugarcane. The experimental design comprised randomized blocks in a $5 \times 2$ factorial scheme, with four replications. Treatments consisted of five levels of water replacement $(100,75,50,25$ and $0 \%$ ), with and without fertirrigation (NK). The planting of sugarcane, cultivar RB85-5453, was performed in a double row (W-shaped), $8 \mathrm{~m}$ long, with $1.80 \mathrm{~m}$ spacing between the double rows, the distance between the crops in the double row was $0.40 \mathrm{~m}$, with a total area of $52,8 \mathrm{~m}^{2}$ in each paddock. For treatments with water, replacement (WR) a drip tube was placed in the ground at a depth of $0.20 \mathrm{~m}$ among the furrows of the double row. The drip tube (DRIPNET PC 16150) comprised a thin wall, 1.0 bar pressure, nominal discharge $1.0 \mathrm{~L} \mathrm{~h}^{-1}$, and $0.50 \mathrm{~m}$ spacing between drippers. Nitrogen was applied by fertirrigation at a dose of $100 \mathrm{Kg} \mathrm{ha}^{-1}$, at 30-day intervals, with 10 applications throughout the development of the sugarcane culture. Potassium fertilization was done partially, in $30 \%$ of the furrows, and the remaining part was treated with the irrigation water. Nitrogen and potassium were spread only in the treatment with $0 \%$ water replacement. Was evaluated hydraulic conductivity and diffusivity versus logarithmic pressure head, at a depth of $10 \mathrm{~cm}$, using RETC software. The hydraulic diffusivity for water replacement of 25 and $50 \%$ with fertigation was 160.3 and $14.9 \mathrm{~cm}^{2}$ days $^{-1}$ for the lower values of the logarithm of the pressure head.
\end{abstract}

Keywords: Saccharum spp.; Infiltration; Pores.

\section{Resumo}

Este trabalho teve como objetivo avaliar o efeito da lâmina de irrigação e da fertirrigação (NK) na condutividade hidráulica e na difusividade de um Latossolo Vermelho distroférrico cultivado com cana-de-açúcar. O delineamento experimental utilizado foi o de blocos ao acaso analisado em esquema fatorial $5 \times 2$, com quatro repetições. Os tratamentos foram compostos por cinco reposições hídricas $(0,25,50,75$ e 100\%), com e sem fertirrigação (NK). Foi cultivada a variedade RB 85-5453, em linha dupla (plantio "em W"), com $8 \mathrm{~m}$ de comprimento, 1,80 m entre linhas de gotejo, o espaçamento entre sulcos foi de $0,40 \mathrm{~m}$, totalizando $52,8 \mathrm{~m}^{2}$ de área total. Para os tratamentos com reposição hídrica, o tubo gotejador foi enterrado a $0,20 \mathrm{~m}$ de profundidade da superfície do solo, no meio da linha dupla. O modelo de tubo gotejador (DRIPNET PC 16150) com parede delgada, pressão de serviço de 1 bar, vazão nominal de $1,0 \mathrm{~L} \mathrm{~h}^{-1}$ e espaçamento entre gotejadores de $0,50 \mathrm{~m}$. O nitrogênio foi aplicado via fertirrigação, na dose 
de $100 \mathrm{~kg} \mathrm{ha}^{-1}$, com intervalos de 30 dias, com 10 aplicações durante todo o desenvolvimento da cultura da cana-deaçúcar. A adubação potássica foi realizada parcialmente no plantio, representando $30 \%$ do total, o restante foi aplicado via fertirrigação. O nitrogênio e potássio foram espalhados apenas no tratamento com reposição de água de $0 \%$. Foi avaliado a condutividade hidráulica e a difusividade versus o logaritmo da carga de pressão, na profundidade de $10 \mathrm{~cm}$, utilizando o software RETC. A difusividade hidráulica para a reposição hídrica de 25 e $50 \%$ com NK foi de 160,3 e 14,9 $\mathrm{cm}^{2} \mathrm{dia}^{-1}$ para os menores valores do logaritmo da carga de pressão.

Palavras-chave: Saccharum spp.; Infiltração; Poros.

\section{Resumen}

Este trabajo tuvo como objetivo evaluar el efecto de la profundidad de riego y fertirrigación (NK) sobre la conductividad y difusividad hidráulica de un Oxisol cultivado con caña de azúcar. El diseño experimental utilizado fueron los bloques al azar analizados en un esquema factorial $5 \times 2$, con cuatro repeticiones. Los tratamientos consistieron en cinco reemplazos de agua (0, 25, 50, 75 y 100\%), con y sin fertirrigación (NK). Se cultivó la variedad RB 85-5453, en doble línea (plantación “en W"), con $8 \mathrm{~m}$ de largo, $1.80 \mathrm{~m}$ entre líneas de goteo, el espaciamiento entre surcos fue de $0.40 \mathrm{~m}$, totalizando $52.8 \mathrm{~m}^{2}$ de área total. Para los tratamientos de reemplazo de agua, el tubo de goteo se enterró a una profundidad de 0,20 m desde la superficie del suelo, en el medio de la doble línea. El modelo de tubo de gotero (DRIPNET PC 16150) con pared delgada, presión de trabajo de 1 bar, caudal nominal de $1,0 \mathrm{~L} \mathrm{~h}^{-1} \mathrm{y}$ distancia entre goteros de $0,50 \mathrm{~m}$. El nitrógeno se aplicó vía fertirrigación, a una dosis de $100 \mathrm{~kg} \mathrm{ha}^{-1}$, a intervalos de 30 días, con 10 aplicaciones a lo largo del desarrollo del cultivo de caña de azúcar. La fertilización con potasio se realizó parcialmente al momento de la siembra, representando el 30\% del total, el resto se aplicó vía fertirrigación. El nitrógeno y el potasio se esparcieron solo en el tratamiento con $0 \%$ de reemplazo de agua. Se evaluó la conductividad hidráulica y difusividad versus el logaritmo de la carga de presión, a una profundidad de $10 \mathrm{~cm}$, utilizando el software RETC. La difusividad hidráulica para el reemplazo de agua de 25 y $50 \%$ con NK fue de 160,3 y $14,9 \mathrm{~cm}^{2}$ día ${ }^{-1}$ para los valores más bajos del logaritmo de carga de presión.

Palabras-clave: Saccharum spp.; Infiltración; Poros.

\section{Introduction}

The hydraulic conductivity of the saturated soil indicates the ability of a soil to transmit water in the unsaturated soil, this conductivity varies with the amount of water present in its empty pores, that is, with its degree of saturation, consequently the hydraulic conductivity is extreme importance to the agricultural use (Gonçalves; Libardi, 2013; Sobrinho et al., 2018).

The saturated soil $\mathrm{K}$ depends on the characteristics of the soil matrix and the fluid present in the soil, it is important both in the flow process and of the transportation of contaminants in porous media, should also consider the soil $\mathrm{K}$ in the solution of problems related to irrigation and the drainage of farm soils (Delgado-Rodríguez et al., 2011).

A detailed understanding of $\mathrm{Ks}$ is critical in the assessment of irrigation practices, infiltration rates, runoff, groundwater recharge rates, and drainage processes, consequently sugarcane is expected to be an important factor that influences the hydraulic properties of soil by affecting its physical and chemical characteristics (Aimrun et al., 2004; Cookson et al., 2007; Breulmann et al., 2012, Hao et al., 2019).

Many researchers have found that the hydraulic conductivity of soil is affected by many factors such as density, water contents, degree of saturation, void ratio, grain size distribution, and particle structure (Chung et al., 2018).

Different hydrological transport models have used hydraulic conductivity at saturation as a constant for chemical leaching risk assessment, water infiltration characterization, and surface runoff modeling, also has been used frequently to predict unsaturated soil hydraulic conductivity (Doussan; Ruy, 2009; Neyshabouri et al., 2013; Masís-Meléndez et al., 2014; Rahmati, 2017; Rahmati et al., 2019).

This study had the objective to evaluate the effect of irrigation and fertigation (NK) in the hydraulic conductivity and diffusivity of an Oxisol cultivated with sugarcane.

\section{Methodology}

The experiment (field study) (Lakatos and Marconi, 2003) was performed in the experimental area of the IFGoiano Campus Rio Verde, GO Brazil, $17^{\circ} 48^{\prime} 28^{\prime \prime S}$ and 50 $53^{\prime} 57^{\prime \prime} \mathrm{W}$, mean altitude $720 \mathrm{~m}$, slightly rolling ground relief (slope $6 \%$ ), 
red dystrophic Latissoil (LVdf) with mean texture 458, 150 and $391 \mathrm{~g} \mathrm{~kg}^{-1}$ sand, silt and clay, respectively, and chemical characteristics as shown in Table 1 .

Table 1. Chemical characterization of soil in the experimental area.

\begin{tabular}{|c|c|c|c|c|c|c|c|c|c|c|c|}
\hline Layer & $\mathrm{pH}$ & OM & $\mathrm{P}$ & K & $\mathrm{Ca}$ & $\mathrm{Mg}$ & $\mathrm{Al}$ & $\mathrm{H}+\mathrm{Al}$ & $\mathrm{S}$ & CTC & V \\
\hline $\mathrm{m}$ & - & $\mathrm{g} \mathrm{dm}^{-3}$ & $\mathrm{mg} \mathrm{dm}{ }^{-3}$ & \multicolumn{7}{|c|}{ - } & $\%$ \\
\hline $0.0-0.2$ & 5.5 & 43.42 & 7.06 & 2.04 & 20.4 & 6.8 & 0 & 57.75 & 0,41 & 69.55 & 41.99 \\
\hline $0.2-0.4$ & 5.6 & 34.47 & 2.65 & 4.09 & 14.4 & 6.2 & 0 & 44.55 & 0,32 & 56.24 & 41.57 \\
\hline
\end{tabular}

$\mathrm{pH}$ in distilled water. P and $\mathrm{K}$ - extractor $\mathrm{Mehlich}^{-1}$. O.M - Organic matter. V - Saturation by bases. Source: Authors.

The experimental design comprised randomized blocks in a $5 \times 2$ factorial scheme, with four replications. Treatments consisted of five levels of water replacement $(100,75,50,25$ and $0 \%)$, with and without nitrogen and potassium ( 0 and $100 \mathrm{~kg}$ $\left.\mathrm{N} \mathrm{ha}^{-1}+56 \mathrm{~kg} \mathrm{~K} \mathrm{ha}^{-1}\right)$.

The planting of sugarcane, cultivar RB855453, was performed in a double row (W-shaped), $8 \mathrm{~m}$ long, with $1.80 \mathrm{~m}$ spacing between the double rows. The distance between the crops in the double row was $0.40 \mathrm{~m}$, with a total area of $35.2 \mathrm{~m}^{2}$ in each paddock. For treatments with water, replacement (WR) a drip tube was placed in the ground at a depth of $0.20 \mathrm{~m}$ among the furrows of the double row. The drip tube (DRIPNET PC 16150) comprised a thin wall, 1.0 bar pressure, nominal discharge $1.0 \mathrm{~L} \mathrm{~h}^{-1}$, and $0.50 \mathrm{~m}$ spacing between drippers. On planting, all furrows of the plots were fertilized with $30 \mathrm{~kg} \mathrm{~N} \mathrm{ha}^{-1}$ (urea), $120 \mathrm{~kg} \mathrm{P}_{2} \mathrm{O}_{5} \mathrm{ha}^{-1}$ (single superphosphate) and $80 \mathrm{~kg} \mathrm{~K}_{2} \mathrm{O} \mathrm{ha}^{-1}$ (potassium chloride). Nitrogen was applied by fertirrigation at a dose of $100 \mathrm{Kg} \mathrm{ha}^{-1}$, at 30-day intervals, with 10 applications throughout the development of the sugarcane culture. Potassium fertilization was done partially, in $30 \%$ of the furrows, and the remaining part was treated with the irrigation water. Nitrogen and potassium were spread only in the treatment with $0 \%$ water replacement.

Water demand was calculated by a $0.1 \mathrm{kPa}$ puncture digital tensiometer. Tensiometric sensors were placed at a depth of $0.20,0.40,0.60$ and $0.80 \mathrm{~m}$, at a distance of $0.15,0.30,0.45$ and $0.60 \mathrm{~m}$ from the drip tube, with daily readings of water tension in the soil. The soil's physical and water characteristics were determined by the water retention curve in the soil, with an available water capacity (AWC) of $100 \mathrm{~mm}$. Soil was kept at field capacity in treatments with 100\% WR. By the end of the experiment, the water supplemented to the soil was calculated to determine the volume of water provided (Table 2).

Table 2. Water volume received at each water replacement level.

\begin{tabular}{cccc}
\hline WR $(\%)$ & WA $(\mathrm{mm})$ & $\mathrm{R}(\mathrm{mm})$ & TVW $(\mathrm{mm})$ \\
\hline 0 & 0 & 1618 & 1618 \\
25 & 126 & 1618 & 1744 \\
50 & 252 & 1618 & 1870 \\
75 & 378 & 1618 & 1996 \\
100 & 504 & 1618 & 2122
\end{tabular}

WR - water replacement; WA - water applied during the experiment; R - rainfall; TVW- Total volume of water received. Source: Authors.

Total evaporation-transpiration and precipitation reached 1549 and $1618 \mathrm{~mm}$, respectively in the treatment without water replacement.

The parameters of the equations that represent the model for the soil was accomplished through the RETC program version 6.02 (van Genuchten et al., 2009). Type of model: retention curve model, conductivity model (van Genuchten, 1980; 
Mualem, 1976), and the soil diffusivity was determined according to Klute (1965) and Pauletto et al. (1988), according to Equation 1 to 3:

$\theta=\theta r+\frac{(\theta s-\theta r)}{\left[1+\left(\alpha \times\left|\psi_{m}\right|\right)^{n}\right]^{m}}$

$\mathrm{K}(\mathrm{Se})=K s \mathrm{~S}_{\mathrm{e}}^{1}\left(\frac{\int_{0}^{S e} \frac{1}{h(x)} d x}{\int_{0}^{1} \frac{1}{h(x)} d x}\right)^{2}$

$\mathrm{D}(\theta)=\mathrm{K} \frac{\partial \mathrm{h}}{\partial \theta}$

where:

$\theta$ - water contents, $\mathrm{cm}^{3} \mathrm{~cm}^{-3}$;

$\theta_{\mathrm{r}}$ - the residual water contents, $\mathrm{cm}^{3} \mathrm{~cm}^{-3}$;

$\theta_{\mathrm{s}}$ - the saturated water contents, $\mathrm{cm}^{3} \mathrm{~cm}^{-3}$;

$\mathrm{m}, \mathrm{n}$ e $\alpha$ - empirical parameter. With $\mathrm{m}=1-1 / \mathrm{n}$;

$\mathrm{h}-$ is the soil water pressure head (with dimension $\mathrm{cm}$ );

$\mathrm{t}$ - is time (days);

$\mathrm{Z}$ - is soil depth $(\mathrm{cm})$;

$\mathrm{K}$ - is the hydraulic conductivity $\left(\mathrm{cm}^{\text {days }} \mathrm{s}^{-1}\right)$;

Ks - is the saturated hydraulic conductivity $\left(\mathrm{cm} \mathrm{days}^{-1}\right)$;

$\mathrm{D}(\theta)$ - soil water diffusivity function $\left(\mathrm{cm}^{2}\right.$ days $\left.^{-1}\right)$.

Results were analyzed by ANOVA. In significant cases, regressions of linear and quadratic were performed for water replacement levels. Nitrogen and potassium application means were compared using Tukey test at significance degree $\alpha=$ 0.05 .

\section{Results and Discussion}

The hydraulic diffusivity (HD) minimum (approximately zero) it was verified in the logarithmic pressure head (LPH) of 4.01, 3.87, 3.95, 3.69 and $4.01 \mathrm{~cm}$ in the water replacement of $0,25,50,75$ and $100 \%$ with fertirrigation and in the LPH of $3.84,4.05,3.69,3.88$ and $3.95 \mathrm{~cm}$ in the water replacement of $0,25,50,75$ and $100 \%$, without fertirrigation, respectively (Figure 1). 
Figure 1. Diffusivity in function of logarithmic pressure head at a depth of $10 \mathrm{~cm}$ for the water replacement of 0 (A), 25 (C), $50(\mathrm{E}), 75(\mathrm{G})$ and $100 \%$ (I) with fertirrigation of NK and of $0(\mathrm{~B}), 25(\mathrm{D}), 50(\mathrm{~F}), 75(\mathrm{H})$ and 100\% (J) without fertirrigation.

A)

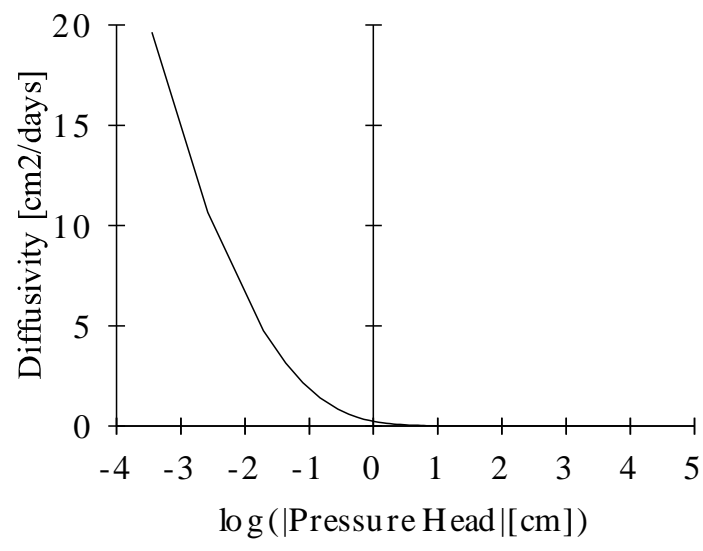

C)

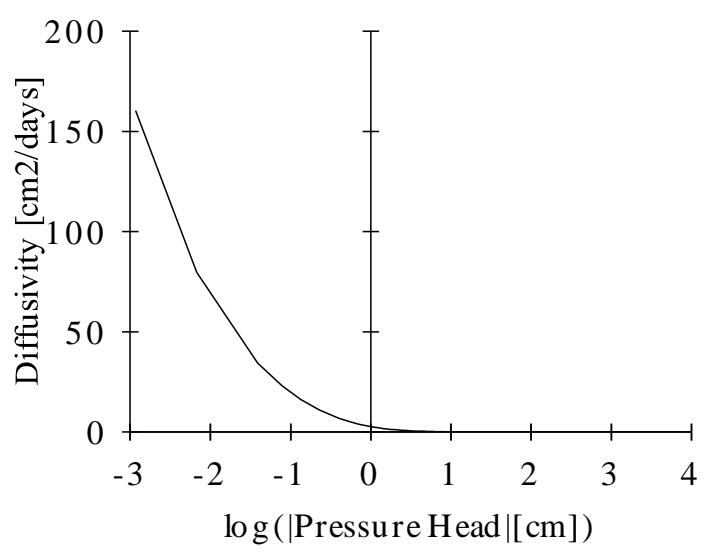

E)

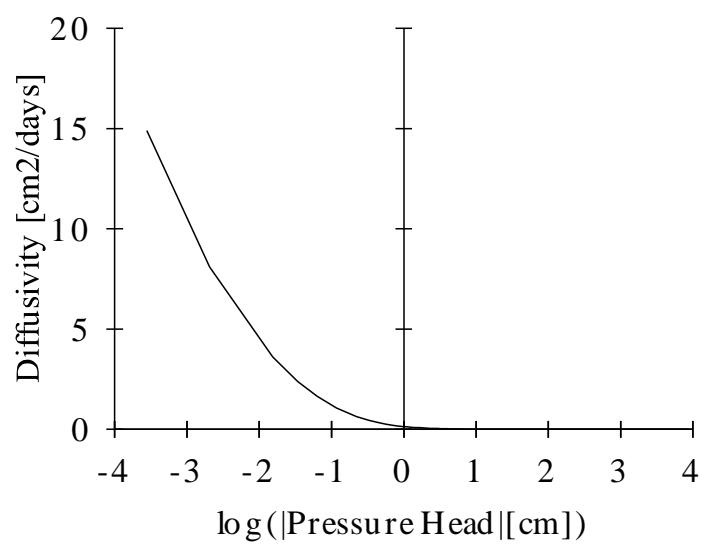

B)

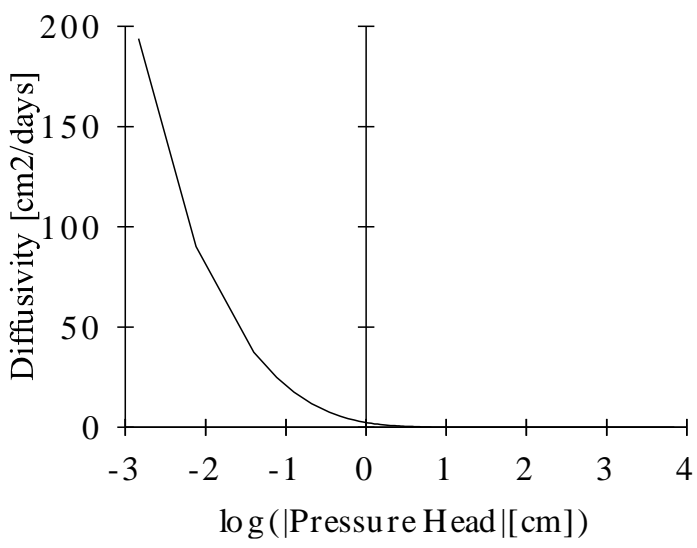

D)

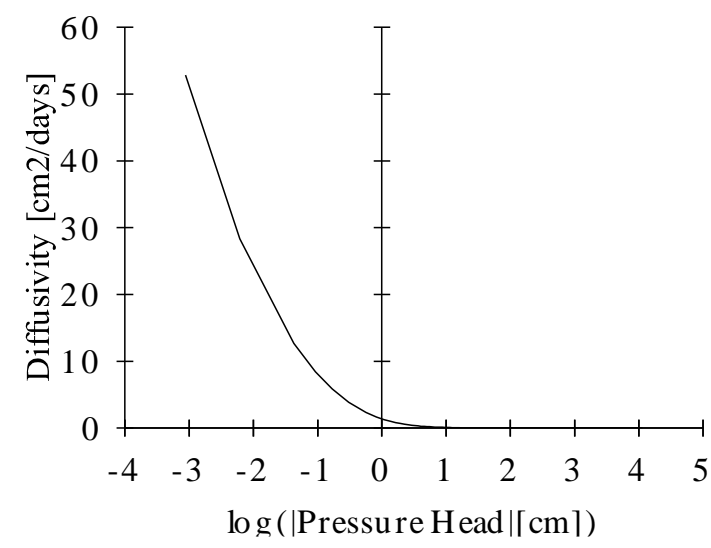

F)

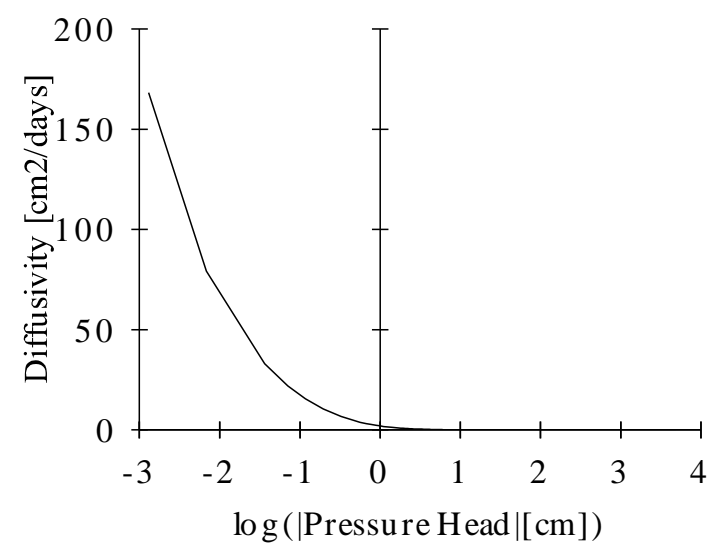


G)

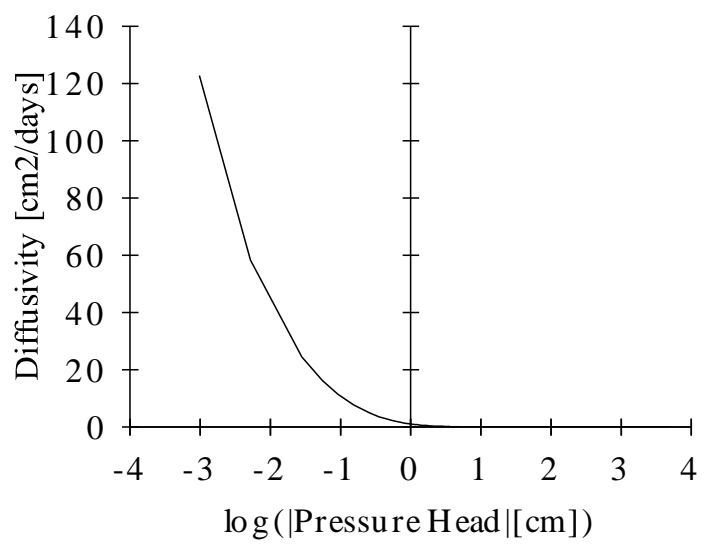

I)

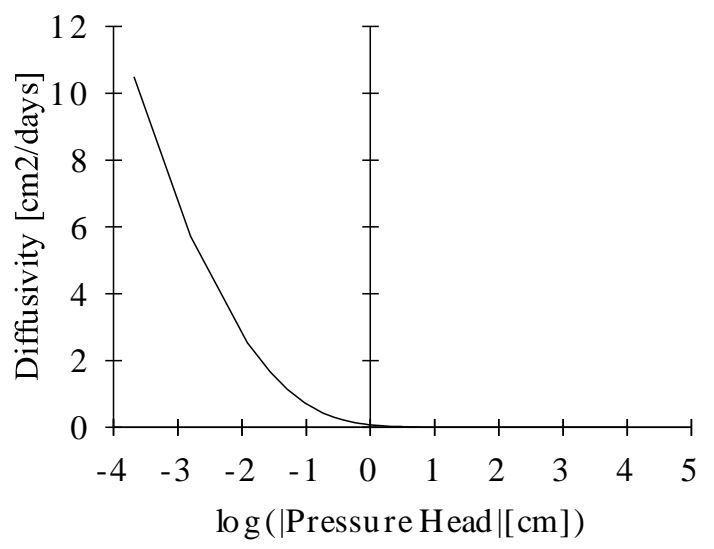

H)

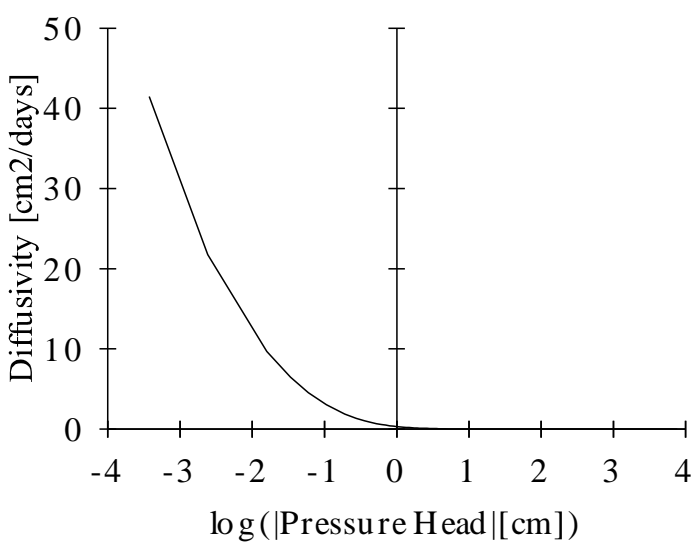

J)

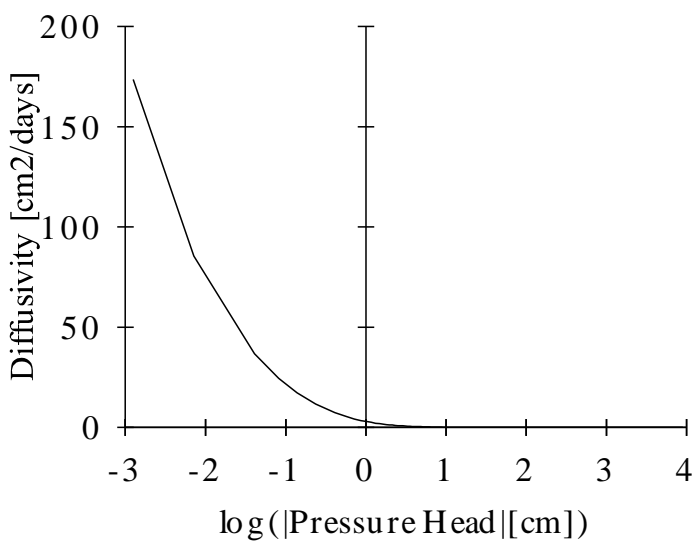

Source: Authors.

According to Cunha et al. (2015) the initial hydraulic diffusivity in the no-tillage system was $16 \%$ higher than the conventional crop diffusivity, this difference has not changed much with the increase of the hydraulic load.

A HD maximum it was of $19.6,160.3,14.9,122.8$ and $10.5 \mathrm{~cm}^{2}$ days ${ }^{-1}$ in the logarithmic pressure head of -3.45 , $2.93,-3.55,-3.01$ and $-3.68 \mathrm{~cm}$ for water replacement of $0,25,50,75$ and $100 \%$ with fertirrigation, and the HD maximum it was of $193.8,52.81,168.3,41.5$ and $173.6 \mathrm{~cm}^{2}$ days $^{-1}$ in the LPH of $-2.83,-3.06,-2.89,-3.43$ and $-2.9 \mathrm{~cm}$ for water replacement of 0,25, 50, 75 and 100\% without fertirrigation, respectively. Determination of soil water diffusivity is important as this hydraulic property is fundamental to characterize unsaturated water and solute transport in soils (Wang et al., 2004).

The HD maximum presented a reduction in 50\%, in the logarithmic pressure head of $-2.5,-2.17,-2.6,-2.28$ and -2.7 $\mathrm{cm}$ in the water replacement of $0,25,50,75$ and $100 \%$ with fertirrigation and in the LPH of $-2.12,-2.2,-2.2,-2.6$ and $-2.15 \mathrm{~cm}$ in the water replacement of $0,25,50,75$ e $100 \%$ without fertirrigation, respectively. Soil water diffusivity and sorptivity depends on the soil productive situation, being negatively affected by soil activities (Villarreal et al., 2016).

The unsaturated hydraulic conductivity (UHC) minimum (approximately zero) it was verified in logarithmic pressure head (LPH) of 4.01, 3.87, 3.95, 3.69 and $4.01 \mathrm{~cm}$ in the water replacement of 0, 25, 50, 75 and 100\%, with fertirrigation, and in the $\mathrm{LPH}$ of $3.84,4.05,3.69,3.88$ and $3.95 \mathrm{~cm}$, in the water replacement of $0,25,50,75$ and $100 \%$, without fertirrigation, respectively (Figure 2). 
Figure 2. Hydraulic conductivity in function of logarithmic pressure head at a depth of $10 \mathrm{~cm}$ for the water replacement of 0 (A), $25(\mathrm{C}), 50(\mathrm{E}), 75(\mathrm{G})$ and 100\% (I) with fertirrigation of NK and of 0 (B), $25(\mathrm{D}), 50(\mathrm{~F}), 75(\mathrm{H})$ and $100 \%(\mathrm{~J})$ without fertirrigation.

A)

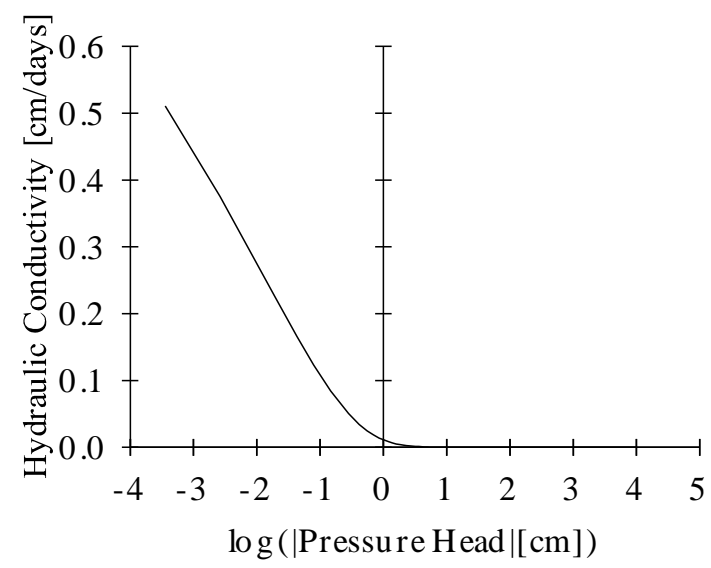

C)

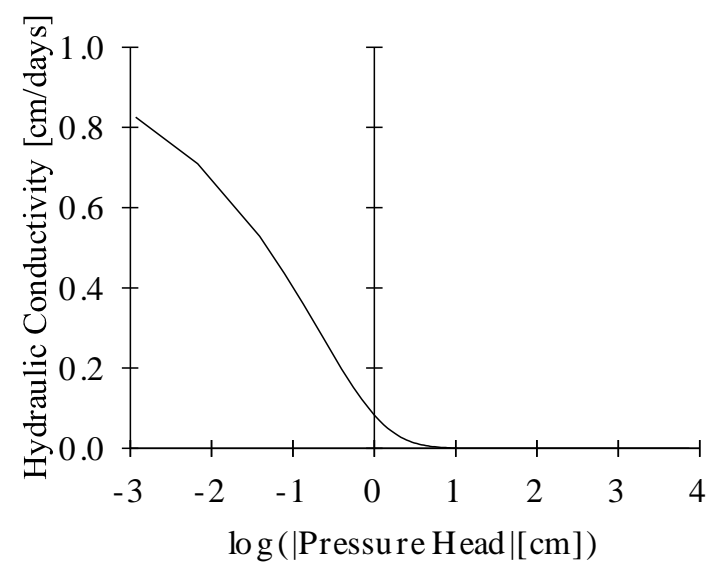

E)

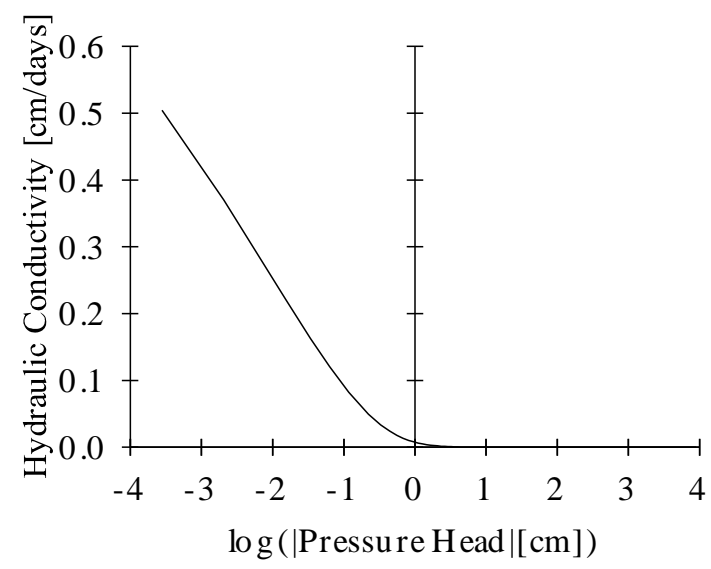

B)

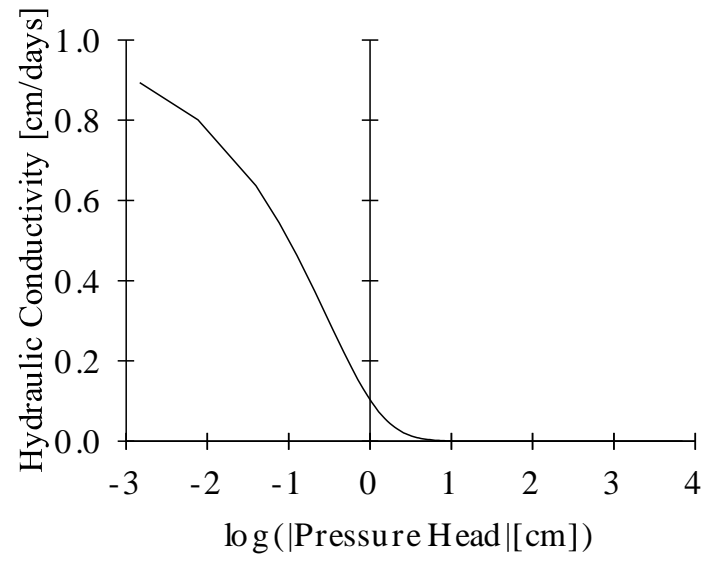

D)

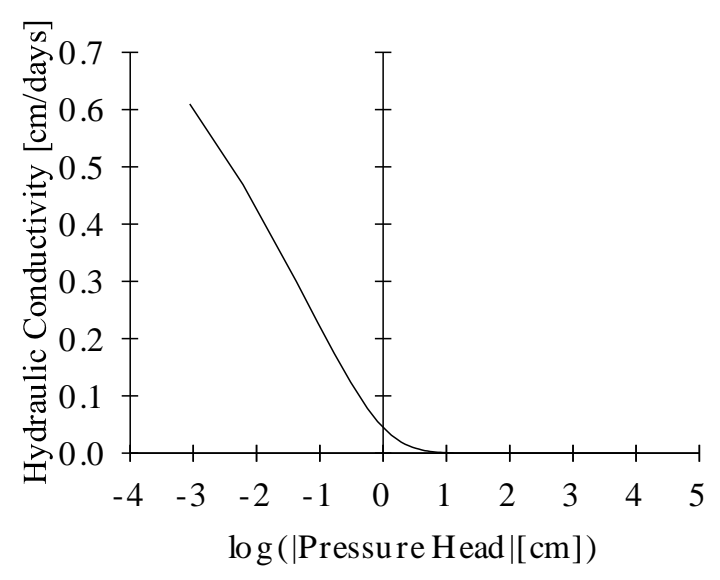

F)

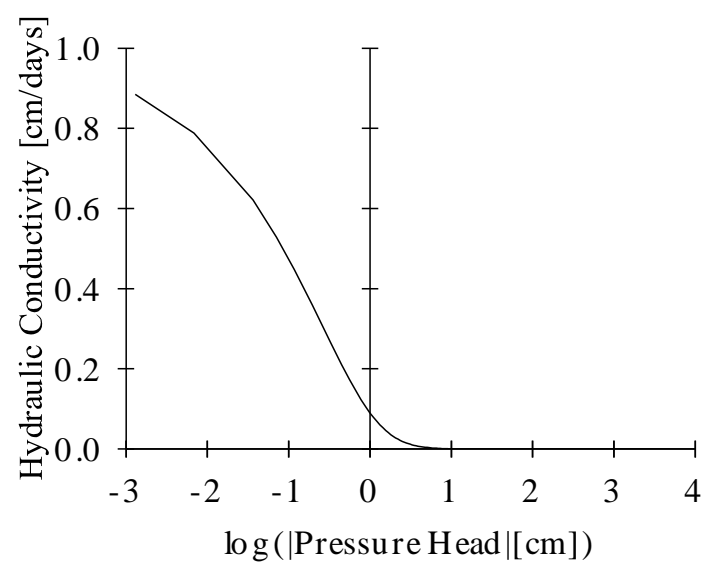


G)

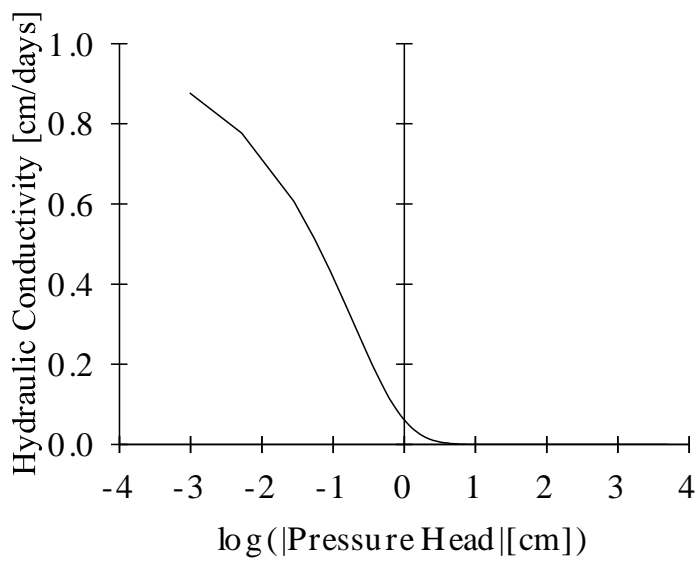

I)

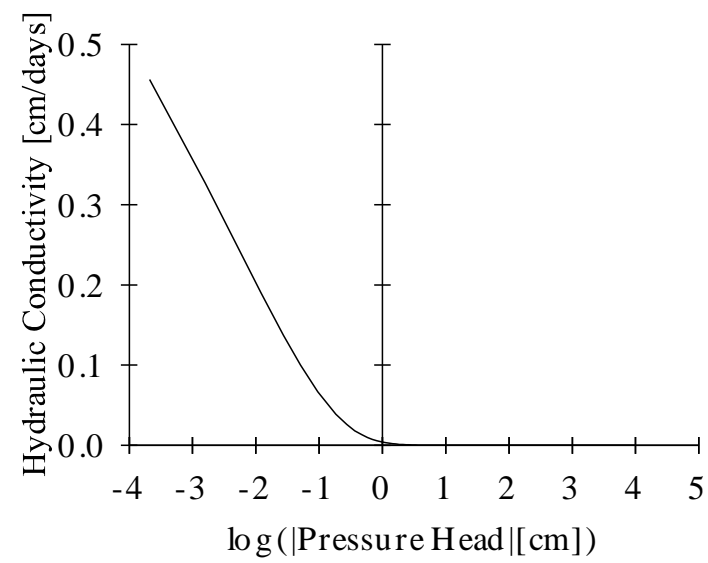

H)

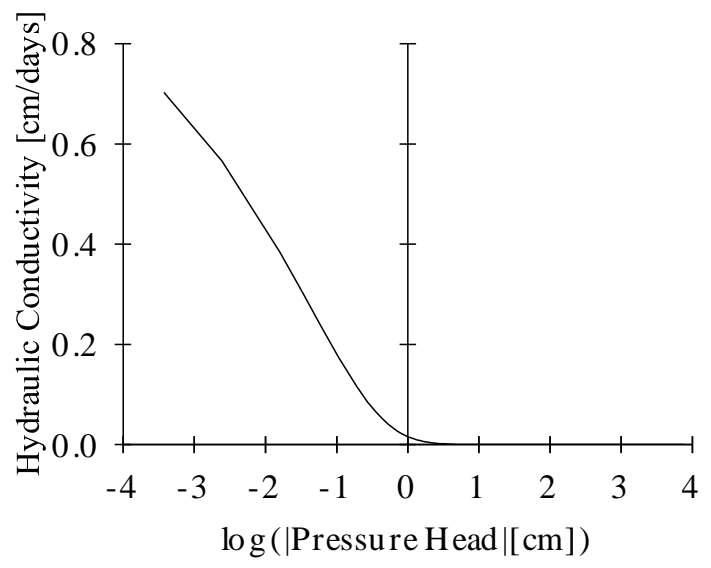

J)

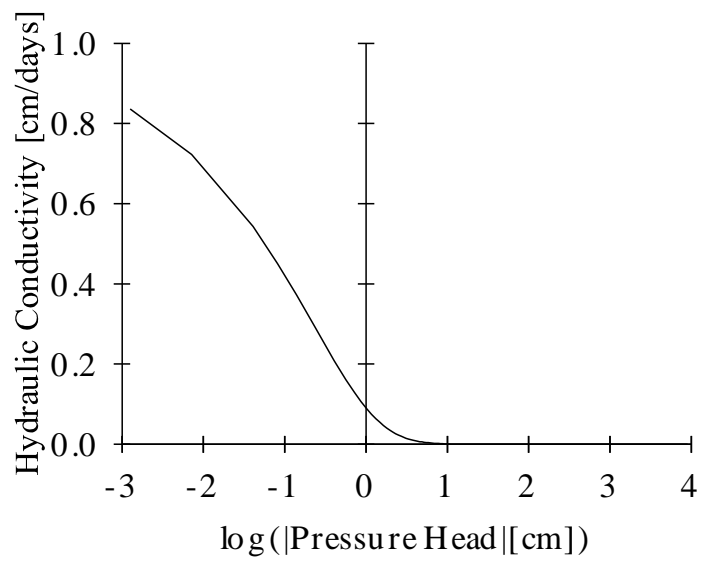

Source: Authors.

The distribution and size of the pores, the tortuosity and connectivity of the pores are the characteristics of the geometry of the porous space that most influence the transport of fluids in the soil (Chief et al., 2006; Brito, 2010).

The UHC maximum it was of $0.511,0.826,0.505,0.877$ and $0.456 \mathrm{~cm}^{\text {days }}{ }^{-1}$ in the logarithmic pressure head of $3.45,-2.93,-3.55,-3.01$ and $-3.68 \mathrm{~cm}$ for the water replacement of $0,25,50,75$ and $100 \%$ with fertirrigation, and the UHC maximum it was of $0.894,0.61,0.885,0.703$ and $0.837 \mathrm{~cm}_{\text {days }}{ }^{-1}$ in the LPH of $-2.83,-3.06,-2.89,-3.43$ and $-2.9 \mathrm{~cm}$ for water replacement of 0,25,50,75 and $100 \%$, without fertirrigation, respectively.

Textural heterogeneity is a crucial factor affecting soil $\mathrm{K}_{\text {sat }}$, but it acts alongside many other ecological factors, such as animal activity, root exudates, soil aggregation, etc. (García-Gutiérrez et al., 2018).

The UHC maximum presented a reduction in 50\%, in the logarithmic pressure head of $-1.8,-1.1,-1.81,-1.04$ and -2.1 $\mathrm{cm}$ in the water replacement of $0,25,50,75$ and $100 \%$ with fertirrigation and in the LPH of $-0.899,-1.37,-0.932,-1.7 \mathrm{e}-1 \mathrm{~cm}$ in the water replacement of 0, 25, 50, 75 and 100\% without fertirrigation, respectively. Eguchi et al. (2016) observed that fertilization does not cause major alterations soil density, macroporosity, microporosity, total porosity or saturated hydraulic conductivity.

The LPH remained positive to UHC of $0.0108,0.0834,0.0064,0.0561$ and $0.0035 \mathrm{~cm}^{\text {days }}{ }^{-1}$ in the water replacement of $0,25,50,75$ and $100 \%$ with fertirrigation and to the UHC of 0.0976, 0.0412, 0.079, 0.0159 and $0.0891 \mathrm{~cm}^{-1 a y s}{ }^{-1}$, in the water replacement of $0,25,50,75$ and $100 \%$, without fertirrigation, respectively. 


\section{Conclusion}

The hydraulic diffusivity for water replacement of 25 and $50 \%$ with fertigation was 160.3 and $14.9 \mathrm{~cm}^{2}$ days $^{-1}$ for the lower values of the logarithm of the pressure head.

The hydraulic conductivity for the water replacement $50 \%$ with and without fertigation was 0.5 and $0.88 \mathrm{~cm} \mathrm{day}^{-1}$ to the logarithm of the pressure head of $-3 \mathrm{~cm}$.

\section{Acknowledgments}

This study was financed in part by the National Council for Scientific and Technological Development (CNPq); the Coordination for the Improvement for Higher Level Personnel (CAPES); the Research Support Foundation of the State of Goiás (FAPEG); the Ministry of Science, Technology, Innovation, and Communications (MCTIC), the Financier of Studies and Projects (Finep) and the Federal Institute of Education, Science, and Technology Goiano (IFGoiano) - Campus Rio Verde.

\section{References}

Aimrun, W., Amin, M. \& Eltaib, S. (2004). Effective porosity of paddy soils as an estimation of its saturated hydraulic conductivity. Geoderma, 121, 197-203.

Breulmann, M., Schulz, E., Weißhuhn, K. \& Buscot, F. (2012). Impact of the plant community composition on labile soil organic carbon, soil microbial activity and community structure in semi-natural grassland ecosystems of different productivity. Plant and Soil, 352, $253-265$.

Brito, A. S. Variabilidade espacial da condutividade hidráulica e da permeabilidade ao ar em função dos conteúdos de água e ar no solo. (2010). Tese (Doutorado) - Escola Superior de Agricultura "Luiz de Queiroz”, Piracicaba.

Chief, K., Ferré, T. P. A., \& Nijssen, B. (2006). Fiel d testing of a soil corer air permeameter (SCAP) in desert soils. Vadose Zone Journal, Madison, 5(4), 1257-1263.

Chung, C-K., Kim, J-H., Kim, J., \& Kim, T. (2018). Hydraulic conductivity variation of coarse-fine soil mixture upon mixing ratio. Hindawi, Advances in Civil Engineering, 2018, 1-11.

Cookson, W., Osman, M., Marschner, P., Abaye, D.A., Clark, I., Murphy, D. V., Stockdale, E. A., \& Watsonf, C. A. (2007). Controls on soil nitrogen cycling and microbial community composition across land use and incubation temperature. Soil Biology and Biochemistry, 39, 744-756.

Cunha, F. N., Silva, N. F., Moura, L. M. F., Teixeira, M. B., Carvalho, J. J., \& Silva, R. T. (2015). Influência da difusividade e condutividade hidráulica na infiltração de água em um latossolo vermelho sob diferentes sistemas de cultivo. Revista Brasileira de Agricultura Irrigada, 9(3) 102 - 112.

Delgado-Rodríguez, O., Peinado-Guevara, H. J., Green-Ruíz, C. R., Herrera-Barrientos, J., \& Shevnin, V. (2011). Determination of hydraulic conductivity and fines content in soils near an unlined irrigation canal in Guasave, Sinaloa, Mexico. Journal of soil science and plant nutrition, 11(3), $13-31$.

Doussan, C., \& Ruy, S. (2009). "Prediction of unsaturated soil hydraulic conductivity with electrical conductivity.” Water Resources Research, 45(10).

Eguchi, E. S., Cecato, U., Muniz, A. S., Mari, G. C., Murano, R. A.C., \& Sousa Neto, E. L. (2016). Mudanças físicas e químicas em solo fertilizado com esterco de aves com e sem escarificação. Revista Brasileira de Engenharia Agrícola e Ambiental, 20 (4), 316-321.

García-Gutiérrez, C., Pachepsky, Y., \& Martín, M. Á. (2018). Technical note: Saturated hydraulic conductivity and textural heterogeneity of soils, Hydrol. Earth Syst. Sci., 22, 3923-3932.

Gonçalves, A. D., \& Libardi, P. L. (2013). Analysis of the soil hydraulic conductivity determination by the instantaneous profile method. Brazilian Science Review, 37(5), 1174-1184.

Hao, M., Zhang, J., Meng, M., Chen, H. Y. H., Guo, X., Liu, S., \& Ye, L. (2019). Impacts of changes in vegetation on saturated hydraulic conductivity of soil in subtropical forests. Sci Rep, 9, 8372 .

Klute, A. (1965). Laboratory measurement of hydraulic conductivity of saturated soil. In: Black, C. A. (Ed.). Methods of soil analysis: part 1. Madison: American Society of Agronomy, 210-221.

Lakatos, E. M., \& Marconi, M. A. (2003). Fundamentos de metodologia científica. 5. ed. São Paulo: Atlas, 1-311.

Masís-Meléndez, F., Deepagoda, T. C., de Jonge, L. W., Tuller, M., \& Moldrup, P. (2014). "Gas diffusion-derived tortuosity governs saturated hydraulic conductivity in sandy soils." Journal of Hydrology, 512, 388-396.

Mualem, Y. (1976). A new model for predicting the hydraulic conductivity of unsaturated porous media. Water Resource Research, 12, 513-522.

Neyshabouri, M. R., Rahmati, M., Doussan, C., \& Behroozinezhad, B. (2013). "Simplified estimation of unsaturated soil hydraulic conductivity using bulk electrical conductivity and particle size distribution." Soil Research, 51(1), 23-33. 
Research, Society and Development, v. 10, n. 6, e23710615402, 2021

(CC BY 4.0) | ISSN 2525-3409 | DOI: http://dx.doi.org/10.33448/rsd-v10i6.15402

Pauletto, E. A., Libardi, P. L., Manfron, P. A., \& Moraes, S. O. (1988). Determinação da condutividade hidráulica a partir da curva de retenção de água. Revista Brasileira de Ciência do Solo, Viçosa, MG, 12, 189-195.

Rahmati, M. (2017). "Reliable and accurate point-based prediction of cumulative infiltration using soil readily available characteristics: A comparison between GMDH, ANN, and MLR.” Journal of Hydrology, 551 .

Rahmati, M., Neyshaboury, M. R. \& Mohammadi, P. (2019). Prediction of soil hydraulic conductivity at saturation using air permeability at any individual soil water content. KSCE J Civ Eng 23, 5226-5234.

Sobrinho, O. P. L., Arriero, S. S., Silva, G. S., Sousa, A. B., \& Pereira, Á. I. S. (2018). Determination of hydraulic conductivity by the Auger-Hole method. BIOFIX Scientific Journal, 3(1), 91-95.

van Genuchten M. T., Leij, F. J., \& Yates, S. R. (2009). RETEC, Code for quantifying the hydraulic functions of unsaturated soils: version 6.02. Riverside: University of California.

van Genuchten, M. Th. (1980). A closed-from equation for predicting the conductivity of unsaturated soils. Soil Science Society of American Journal, Madison, 44, 892-898.

Villarreal, R., Lozano, L. A., Soracco, C. G., Filgueira, R. R., \& Sarli, G. O. (2016). Soil water diffusivity: A simple laboratory method for its determination. Water Resources and Irrigation Management, Salvador, BA, 5(1), 15-21.

Wang, Q., Shao, M., \& Horton, R. (2004). A simple method for estimating water diffusivity of unsaturated soils. Soil Sci. Soc. Am. J., 68, 713-718. 